\title{
Parikan Kentrung Blora: A Javanese Pantoum Variation
}

\author{
Agus Yuwono ${ }^{1}$, Rustono ${ }^{2}$, Hari Bakti Mardikantoro ${ }^{3}$, Teguh Supriyanto ${ }^{4}$ \\ \{agusyuw@yahoo.co.id ${ }^{1}$,rus_tono58@yahoo.co.id ${ }^{2}$, haribaktim@gmail.com ${ }^{3}$ \\ Universitas Negeri Semarang, Semarang ${ }^{1}$, Universitas Negeri Semarang, Semarang ${ }^{2}$, Universitas \\ Negeri Semarang, Semarang 3
}

\begin{abstract}
In number of developed countries, analysis on tourism tendency has been developed academically and institutionalized. This kind of study is considered sufficient if it is implemented in Kentrung performing arts. Kentrung is one of typical art from Blora regency. It is considered a complex art show comprises several sub elements, i.e. narrative story, music, drama, and parikan or pantoum. The target is to describe: the form of Blora Regency's Javanesse pantoum, its function, as well as its meaning. Results show that the form of a Javanesse Pantoum consists of intervowen quatrains known as sampiran (the pun) and isi (the content). Sampiran is merely created as the introductory part before the actual content in the last two lines. The relation between sampiran and isi is not in terms of its meaning or purpose, but more to the relation of sounds in which the repetition of pattern can be found.
\end{abstract}

Keywords: Javanese pantoum, pantoum, narrative, sampiran, isi.

\section{Introduction}

Tourism is a universal human need. Objectivelly, the need of tourism usually appears regardless the time and space influencing it. For that, a deep analysis towards tourism tendency as a scientific disciplines needs to be done. From its implementation perspective, a systematic, pragmatic, and functional management for tourism creation and business utilization, has become an urgent demand to be met. This may answer concerns related to national economic development in the non-oil and gas sector, as well as developments in the international economic situation.

Kentrung is a typical art from Blora Regency in the form of fairy tale. This art is considered fragile since it is almost extinct. This art is only played and performed by one generation, named Zaenuri from Sendanggayam Village, Banjarejo, Blora. Kentrung is played by a puppeteer who beat tambourine while performing. The puppeteer plays music while speaking. The tale he delivers is taken from ancient tales containing wise philosophy.

Based on these conditions, the development of Kentrung art as an effort to increase the cultural tourism industry in Blora Regency is very necessary.

This was carried out under main consideration that Blora District is placed between North and South Kendeng Mountains with land composition of 56 percent gromosol, 39 percent Mediterranean and 5 percent alluvial. This condition is very unfavorable for Blora people to rely only on agriculture. 
With only one generation named Zaenuri from Sendanggayam Village, Banjarejo, Blora to perform the and develop the arts, thus, the attempt to develop the arts will help the inventory of the traditional arts and more importantly, to develop the arts as one of assets in the tourism industry.

\section{Research Methods}

This research employs qualitative method. A qualitative approach tries to understand phenomenon as part of a comprehensive system, which contains detailed explanations related to the related and spesific scope. Bogdan and Taylor define qualitative as a research procedure resulted in descriptive data in written and spoken from research participant whose behaviour is observable.

The location and subject of this study is in Sendanggayam village, Blora Regency. The data collection techniques are employing (1) observation, (2) interview, (3) documentation study. The observation was done during the Kentrung performance; interview was conducted with several interviewees, meanwhile the documentation study was done by analyzing and studying related written documents and the video- taped performance.

The data analysis in this study was carried out with descriptive-qualitative analysis method in which the data was described. In more details, the research steps are as follows:

(1) Data Collection, (2) Organization, and (3) Data Grouping based on the nature and category of the existing data. These steps also belongs to data reduction ad data presentation. To avoid bias, data validation was done by paying attention to four criteria: degree of trust, transferability, dependence, and certainty.

\section{Results and Discussion}

Kentrung is a kind of traditional folk art that is still alive and liked by people, specifically in Blora and surrounding areas. The music instruments used are three tambourines in different size, small, medium, and big. If it is seen from the tool limitation, then it is understandable if Blora's Kentrung which is played by only one person. This Kentrung is essentially used as music accompaniment to the disclosure of folklore, which is performed by a puppeteer. The performed folklore is related to the spread of Islam in Java.

Seeing from the form, Blora's kentrung performance is a monologue or speaking performance, played by a puppeteer who also playing the music by himself. In more details, the elements shaping the Kentrung performance are the puppeteer, music accompaniment, and the story line. The more detailed information of each element is as follows:

1) The puppeteer: The puppeteer tells story with speaking while playing music at the same time. On stage, a puppeteer will sit cross-legged while holding his instrument. A puppeteer is a director, writer, narrator, actor, music director, singer, as well as stage manager at the same time. A puppeteer is someone with double ability, and also a manager, or a leader in his own performance. A puppeteer is a story teller who direct the story line.

2) Music accompaniment: The music accompaniment of the Kentrung art is named 'Terbang', which is three tambourines in 3 different sizes, small, medium, and big. The smallest and the medium tambourine are completed with kecer which 
will produce clinking sound when it is hit. The big tambourine is not accompanied by kecer.

3) Story (in the form of narrative, dialogue, and Javanese pantoum) means story or the second important element in Kentrung performance. The storyline taken by a puppeteer is a story about Wali or Islamic religious leader who spread Islam in java which story is mainly told in middle ages Javanese literature. The Kentrung story comprised of 3 forms, narrative, dialogue, and pantoum. The narrative is used to initiate the story tells about the setting and dialogue is converstaion between characters in the play. Meanwhile the parikan is a form of Javanese traditional pantoum.

\subsection{The form of Parikan Kentrung in Blora Regency}

The word parikan is formed from the word 'pari' and suffix -an. The word 'pari' which means padi or rice plant, in its krama or softer language means pantoum. The form of 'parikan' is exactly like the Indonesian pantoum. A Javanese pantoum or parikan consists of sampiran and isi. Sampiran is the pun, isi is the content. There is no relation between the content and the pun or between isi and sampiran. Sampiran is created only as an introductory part towards the actual isi or content.

More precisely, sampiran is the first and second lines of a pantoum. The last sound of sampiran is made similar with the one in the content part (isi). However, there is no specific relation between sampiran and isi. The two share similar last sound in the last line and not the content.

In general, parikan is divided into two different forms, single Javanese pantoum which consists of two line pantoum and double Javanese pantoum which consists of four line pantoum. In the single parikan, the first gatra or line is sampiran and the second gatra or line is easy. Meanwhile, in double pantoum, two first lines are sampiran, and two last lines are isi.

In Indonesian language, there are many forms and kinds of pantoums. There are two line pantoum, four line pantoum, eight line pantoum, etc. Pantoum consits of more than four lines is called talibun.

Besides, there is also another pantoum named pantun berkait. In addition, the forms of pantoum also differemt in terms of its content. There is nasihat which content is advice, adat or custom, agama or relogion, teka-teki or riddle, as well as proverb.

Some examples of parikan found in kentrung performance in Blora regency is as follows:

Sing bener lakonana

Sing wis bener suwarane

Ngombe wedang kopi cangkir tutupane

Nek wis adem kowe ore melu melu ngonbe

Nek karep (rabi) ora bisa keturutane

Anake gelem wis kowe dadi nano...(pepalange)

Dereng dangu mas sing dadi lakune

Nake mampir pasare sore

Pasar blora mas sing pasare gedhe

Nek sesuk akeh mas sing bakule tempe

Mangke malih dipun dugekake

Leren sedela badhe ngombe 
From the example, the lines in the pantoum consists of 6 different lines, however two first lines are only introduction, two lines in the middle are sampiran, and the last two lines are the isi or content. Two lines used as introductory lines are:

Sing bener lakomomo

Sing wis bener suwarane

Dereng dangu mas sing dadi lakune

Nake mampir pasare sore

The other four lines are the actual Javanese pantoum, there are:

Ngombe wedang kopi cangkir tutupan

Nek wis adem kowe ore melu melu ngobe

Nek karep (rabi) ora bisa keturutane

Anake gelem wis kowe dadi nano...(pepalange)

\subsection{The Function of Parikan Kentrung (Kentrung Pantoum) in the Blora Regency}

Based on the form and data, we can find at least two parikan or pantoum functions, namely, first, as a projection system. It is when a pantoum is used as a tool to reflect the imagination of a collective as well as a means of ratifying while at the same time also functioned as an entertainment tool.

This projection system was conveyed through wishful thinking and the puppeteer speech. The puppeteer as the narrator, for example, tells that marriage is sometimes blocked by community institutions for example related to the neton, birth number, direction of the house as found in some Javanese primaries. Aside from being a projection of course as a public entertainment. This actualization can be seen in the desire of the puppeteer to rest between the shows by saying utterences, like Mangke malih dipun dugekake (I will continue later), Leren sedela badhe ngombe (I will rest for a while to drink (coffee, tea, not alcoholic one).

The condition of the puppeteer may be beyond the attention of the audience, so when he wants to drink, for example, the puppeteer chooses to use parikan or Javanesse pantoum to create a funny atmosphere.

\subsection{The Meaning of Parikan Kentrung in Blora Regency}

The meaning of parikan is the intent or content contained in the Javanese pantoum that can be captured by the listener or reader according to the level of experience and knowledge. Therefore, the meaning of a Javanese pantoum will vary when the interpretation is not the same. Even, it is usually the opposite. In interpretation, there will definitely be an element of subjectivity. Maturity, stability of experience, and knowledge of the interpreter will determine the quality of the meaning of a poetry. Thus, only the poet knows the exact meaning of the poem.

Other things related to poetry appreciation are understanding of intrinsic and extrinsic elements. Intrinsic elements of poetry include themes, diction, lines, rhyme, meaning, and moral value. In addition, the extrinsic elements are the background of the author, the condition of society at the time the poem was composed, social, political, customary, etc. Based on the data collected, therefore, Parikan Kentrung is the harmony of humans and their environment. The 
meaning of harmony comprises the good relation between human and nature; and harmony between neighbors.

\section{Conclusion}

This section contains conclusions and suggestions.

1. Parikan kentrung consists of 6 lines, the first two lines are only the introductory sentence to parikan, the second two lines are sampiran, and the next two lines are contents or $i s i$.

2. As a culture of a collective, the existence of the people is not without roles or functions at all, there are at least seven functions of Blora's society, namely: as a projection system, as a means of ratifying cultural institutions and institutions, as children's educational tools, as a means of forcing and monitoring so that community norms stand, as social control tools, as a means to protest injustice, and as an entertainment tool.

3. The meaning of Parikan Kentrung is the harmony between human and nature, as well as between neighbours.

The suggestion for this study is the need for further research related to the narrative of Kentrung, especially the variety, the pantoum, the dialogue, and narration. The three forms will at least help to maintain the essence of art in the midst of exposure to other modern music.

Acknowledgments. Throughout the writing of this dissertation I have received a great deal of support and assistance. I would first like to thank my supervisors Prof. Dr. Rustono from Universitas Negeri Semarang, Dr. Hari Bakti Mardikantoro from Universitas Negeri Semarang, and Prof. Dr, Teguh Supriyanto whose expertise was invaluable in the formulating of the research topic and methodology in particular. In addition, I owe a huge debt of gratitude to my family for immense support, love, patience, and encouragement throughout my study. 


\section{References}

[1] Abdulah, Irwan.: Agama dan Kearifan Lokal dalam Tantangan Global. Yogyakarta: Sekolah Pascasarjana UGM (2008)

[2] Darma, Budi.: Pengantar Teori Sastra. Jakarta: Penerbit Buku Kompas (2019)

[3] Endraswara.: Suwardi.: Antropologi Sastra Lisan: Perspektif, Teori, dan Praktik Pengkajian. Jakarta: Yayasan

[4] Pustaka Obor Indonesia (2018)

[5] Faruk.: Metode Penelitian Sastra. Yogyakarta: Pustaka Pelajar (2012) [5] Jabrohim.: Teori Penelitian Sastra. Yogyakarta: Pustaka Pelajar (2015)

[6] Kaelan.: Filsafat Bahasa, Semiotika, dan Hermeneutika. Yogyakarta: Paradigma (2009) [7] Parera.: Teori Semantik. Jakarta: Penerbit Erlangga (2004)

[7] Sudikan, Setya Yuwana.: Metode Penelitian Sastra Lisan. Lamongan: CV Pustaka Ilalang Grup (2014)

[8] Sumarsono.: Pengantar Semantik. Yogyakarta: Pustaka Pelajar (2007)

[9] Moleong.: Metodologi Penelitian Kualitatif. Bandung: PT Remaja Rosdakarya (2017) 